\author{
А.I. Ільницький ${ }^{1}$, O.I. Бурба ${ }^{2}$ \\ ${ }^{1}$ Інститут телекомунікаційних систем НТУУ «КПI», Київ \\ ${ }^{2}$ Військова частина А1906, Київ
}

\title{
СТАТИСТИЧНІ ОЦІНКИ НЕЗМІЩЕНОСТІ ТА ЕФЕКТИВНОСТІ ПАРАМЕТРІВ ДЖЕРЕЛ ВИПРОМІНЮВАННЯ ПРИ РАДІОМОНІТОРИНГУ ТЕЛЕКОМУНІКАЦІЙНИХ МЕРЕЖ І СИСТЕМ
}

Стаття присвячена висвітленню особливостей отримання статистичних оцінок параметрів джерел радіовипромінювання і характеристик їх незміщеності, ефективності та оптимальності у процесі ведення радіомоніторингу з моноімпульсним визначенням відносного пеленгу радіотехнічних елементів телекомунікаційних систем. Завдання вимірювання параметрів джерел радіовипромінювань розглядається як завдання оцінювання параметрів розподілу щүільності імовірності за даними вибірки вхідної випадкової статистики.

Ключові слова: статистичні оцінки, точність пеленгування, джерело радіовипромінювань, радіомоніторинг, моноімпульсне пеленгування, телекомунікаційні системи, незміщеність, ефективність, оптимальність.

\section{Вступ}

Відомо $[1,2]$, що сучасні телекомунікаційні системи (ТКС) виконують велику кількість завдань та відрізняються значною різноманітністю як структурної, так й функціональної побудови і навантаженням за призначенням. Глобальну ТКС можна розглядати як багатофункціональну параметричну радіотехнічну систему, кожний елемент якої у сукупності створює складну радіоелектронну обстановку (РЕО). Складність сучасної РЕО обумовлена такими основними факторами: постійним збільшенням та різноманіттям джерел радіовипромінювання (ДРВп) на фоні обмежених ресурсів наявних сил та засобів радіомоніторингу (РМ); широким діапазоном робочих частот ТКС (від 30 МГц до 400 ГГц) і тривалості сигналів ДРВП (десятки нс - сотні мкс); високою щільністю потоку сигналів ДРВп в точці прийому, яка може досягати $10^{5}-10^{7}$ імпульсів в секунду; застосуванням сигналів зі складною частотно-часовою структурою та інформаційним наповненням; використанням енергетично прихованих режимів роботи, в тому числі 3 короткочасними сеансами випромінювання; появою i використанням відносно нових, наприклад, SDR (Software - defined radio) технологій побудови і експлуатації приймально-передавальних пристроїв ТКС.

Постановка проблеми у загальному вигляді. Загальний контроль за станом РЕО - радіомоніторинг (РМ) - здійснюють сили і засоби "Українського державного центру радіочастот та нагляду за зв'язком". Вони визначають умови енергетичного та структурного доступу до ДРВп з метою контролю і забезпечення електромагнітної сумісності радіотехнічних систем, що є запорукою високої ефективності роботи ТКС [3]. При цьому під час РМ повинні визначатися як енергетичні, так і частотно-часові та просторові параметри ДРВп в середовищі ТКС (по- тужність імпульсних і безперервних сигналів, їх миттєва частота та іï девіація, тривалість імпульсів і період повторення, ширина спектра і вид модуляції сигналів, значення пеленга на ДРВп та його місцеположення тощо).

Однак на думку як науковців, так і операторів ТКС поряд з загальним контролем стану РЕО та виконання умов електромагнітної сумісності засобами ДРВп необхідно мати і автономні засоби РМ, які мають бути задіяні та розташовані безпосередньо на приймально-передавальної апаратурі ТКС для здійснення оперативного контролю.

Слід зазначити, що технічні засоби РМ працюють в складних умовах часткової або повної невизначеності, при цьому в результаті контролю отримуються не параметри ДРВп, а їх статистичні оцінки, яки повинні задовольняти умовам Крамера-Рао і бути незміщеними, ефективними та оптимальними [3]. Велика точність цих статистичних оцінок параметрів сигналів, отриманих в реальному масштабі часу, гарантує високу ефективність РМ і працездатність ТКС. Тому проблемні питання, які обумовлені завжди існуючими суперечливостями між високими вимогами до ефективності технічних засобів РМ та їх реальними можливостями, вимагають постійного подальшого розвитку теорії і практики апаратно-програмних засобів радіоконтролю, створення нових і модернізації існуючих зразків спеціального обладнання.

Аналіз останніх досліджень і публікацій. Проведений аналіз стану технічного оснащення сил i засобів радіоконтролю, технічних характеристик обладнання (апаратури контролю) свідчить про те, що проблемні питання щодо підвищення їх ефективності залишаються актуальними. Разом с цим, останнім часом у відомої науково-технічної літературі з'являються відомості про нові наукові та практичні результати в галузі теорії і практики радіокон- 
тролю: нові та уточнені математичні моделі процесів РМ, нові і удосконалені методи, способи і методики вимірювання основних параметрів ДРВп та апаратно-програмні пристрої їх реалізації [4 - 6]. Однак, слід звернути увагу, що автори нових розробок в цей предметної області обмежуються лише отриманням наукових результатів на ідейнопринциповому рівні [7 - 9], і багато питань практичного значення залишається поза їх увагою.

В якості прикладу можна розглянути використання SDR (Software - defined radio) технологій побудови i експлуатації приймально-передавальних пристроїв ТКС [4], де застосовуються програмні зміни робочих радіочастотних параметрів сигналів (вихідна потужність, діапазон зміни робочих частот тощо), які можуть змінюватися як детерміновано, так і випадково). Природно, що радіоконтроль таких ДРВп є складним науковим і практичним завданням та потребує особливої уваги. Найактуальнішими стають питання миттєвого отримання з високою точністю енергетичних і частотно-часових оцінок параметрів ДРВп та їх моноімпульсного пеленгування 3 подальшим визна- ченням місцеположення ТКС, яки підлягають контролю в реальному масштабі часу.

На підставі наведеного метою $\boldsymbol{i}$ основним змістом статmі є висвітлення результатів аналізу умов отримання незміщених, ефективних та оптимальних статистичних оцінок точності при пеленгуванні джерел радіовипромінювань двоканальними фазовими моноімпульсними пеленгаторами, як апаратно-програмними засобами радіомоніторингу телекомунікаційних мереж і систем.

\section{Виклад основного матеріалу}

В [5] запропоновано спосіб двоканального фазового моноімпульсного пеленгування джерел радіовипромінювання станціями радіомоніторингу, а в [6] пристрій його реалізації, яки в сукупності створюють апаратно-програмний засіб радіомоніторингу для аналізу РЕО в середовищі ТКС. Також описано процес отримання достатньо точних оцінок відносного пеленгу на ДРВп $\beta^{*}$, які обчислюються з використанням квадратурних складових прийнятих сигналів в пеленгаційних каналах за виразом:

$$
\begin{aligned}
& \beta^{*}=\arcsin \left(\frac{\lambda_{\mathrm{H}}^{*}}{2 \pi \mathrm{d}} \operatorname{arctg} \frac{\mathrm{U}_{1}}{\mathrm{U}_{2}}\right)=\arcsin \left(\frac { \lambda _ { \mathrm { H } } ^ { * } } { 2 \pi \mathrm { d } } \operatorname { a r c t g } \left(\left[\int_{\mathrm{t}-\mathrm{T}}^{\mathrm{t}} \mathrm{x}_{1}(\mathrm{t}) \cos \omega_{\mathrm{H}} \mathrm{tdt} \int_{\mathrm{t}-\mathrm{T}}^{\mathrm{t}} \mathrm{x}_{2}(\mathrm{t}) \sin \omega_{\mathrm{H}} \mathrm{tdt}-\int_{\mathrm{t}-\mathrm{T}}^{\mathrm{t}} \mathrm{x}_{1}(\mathrm{t}) \sin \omega_{\mathrm{H}} \mathrm{tdt} \times\right.\right.\right. \\
& \left.\left.\times \int_{\mathrm{t}-\mathrm{T}}^{\mathrm{t}} \mathrm{x}_{2}(\mathrm{t}) \cos \omega_{\mathrm{H}} \mathrm{tdt}\right] /\left[\int_{\mathrm{t}-\mathrm{T}}^{\mathrm{t}} \mathrm{x}_{1}(\mathrm{t}) \cos \omega_{\mathrm{H}} \mathrm{tdt} \int_{\mathrm{t}-\mathrm{T}}^{\mathrm{t}} \mathrm{x}_{2}(\mathrm{t}) \cos \omega_{\mathrm{H}} \mathrm{tdt}+\int_{\mathrm{t}-\mathrm{T}}^{\mathrm{t}} \mathrm{x}_{1}(\mathrm{t}) \sin \omega_{\mathrm{H}} \mathrm{tdt} \int_{\mathrm{t}-\mathrm{T}}^{\mathrm{t}} \mathrm{x}_{2}(\mathrm{t}) \sin \omega_{\mathrm{H}} \mathrm{tdt}\right]^{-1}\right),
\end{aligned}
$$

де $\lambda_{\mathrm{H}}^{*}$ - оцінка довжини хвилі вхідного сигналу 3 несучою частотою $\omega_{\text {н }}$, яка відома, або вимірюється окремим вимірювачем миттєвої частоти; $\mathrm{d}$ - величина фазометричної бази антенної системи пеленгатора; $\quad \mathrm{x}_{1}(\mathrm{t})=\mathrm{S}_{1}(\mathrm{t})+\mathrm{n}_{1}(\mathrm{t}) ; \mathrm{x}_{2}(\mathrm{t})=\mathrm{S}_{2}(\mathrm{t})+\mathrm{n}_{2}(\mathrm{t})-$ сигнально-завадова суміш у приймальних каналах пеленгатора; $\mathrm{S}_{1}(\mathrm{t})=\mathrm{S}(\mathrm{t}) \cos \left[\omega_{\mathrm{H}} \mathrm{t}+\phi+\psi(\mathrm{t})\right] ; \quad \mathrm{S}_{2}(\mathrm{t})=$ $=\mathrm{S}(\mathrm{t}) \cos \left[\omega_{\mathrm{H}} \mathrm{t}+\phi+\psi(\mathrm{t})\right]-$ корисні сигнали на вході приймальних каналів пеленгатора; $\phi=\pi \mathrm{d} / \lambda_{\mathrm{H}} \cdot \sin \beta$; $\mathrm{n}_{1}(\mathrm{t})=\mathrm{N}_{1}(\mathrm{t}) \cos \left[\omega_{0} \mathrm{t}-\phi_{1}(\mathrm{t})\right] ; \quad \mathrm{n}_{2}(\mathrm{t})=\cos \left[\omega_{0} \mathrm{t}-\phi_{2}(\mathrm{t})\right] \times$ $\times \mathrm{N}_{2}(\mathrm{t})$ - незалежні внутрішні шуми у приймальних каналах пеленгатора; $\mathrm{U}_{1}$ - сигнал різницевого каналу фазометричної обробки; $\mathrm{U}_{2}$ - сигнал сумарного каналу фазометричної обробки; $\mathrm{x}_{1}(\mathrm{t}) \cos \omega_{\mathrm{H}} \mathrm{t}=\mathrm{x}_{1 \mathrm{c}}$ та $\mathrm{x}_{1}(\mathrm{t}) \times$ $\times \sin \omega_{H} \mathrm{t}=\mathrm{x}_{1 \mathrm{~s}} ; \quad \mathrm{x}_{2}(\mathrm{t}) \cos \omega_{\mathrm{H}} \mathrm{t}=\mathrm{x}_{2 \mathrm{c}} \quad$ та $\quad \mathrm{x}_{2}(\mathrm{t}) \sin \omega_{\mathrm{H}} \mathrm{t}=$ $=\mathrm{x}_{2 \mathrm{~s}}-$ квадратурні (c - косинусоідальна, $\mathrm{s}$ - синусоідальна) складові сигналів $\mathrm{x}_{1}(\mathrm{t})$ та $\mathrm{x}_{2}(\mathrm{t})$ відповідно.

Наведений вираз (1) для подальшого аналізу отриманої оцінки пеленгу зручніше надати в вигляді:

$$
\beta^{*}=\arcsin \left(\frac{\lambda_{\mathrm{S}}}{2 \pi \mathrm{d}} \times \operatorname{arctg} \frac{2\left(\mathrm{x}_{1 \Delta \mathrm{c}} \mathrm{x}_{2 \Sigma \mathrm{s}}-\mathrm{x}_{1 \Delta \mathrm{s}} \mathrm{x}_{2 \Sigma \mathrm{c}}\right)}{\left(\mathrm{x}_{1 \Sigma \mathrm{c}}^{2}+\mathrm{x}_{2 \Sigma \mathrm{s}}^{2}\right)-\left(\mathrm{x}_{1 \Delta \mathrm{c}}^{2}+\mathrm{x}_{2 \Delta \mathrm{s}}^{2}\right)}\right),
$$

де індекси $\Delta \mathrm{i} \sum$ при $\mathrm{x}_{1}$ та $\mathrm{x}_{2}$ вказують на різнице- вий і сумарний канали апаратурної обробки квадратур сигналів $\mathrm{x}_{1}$ та $\mathrm{x}_{2}$ відповідно.

Обчислення тригонометричних функцій $\operatorname{arctg} \mathrm{i}$ $\arcsin$ здійснюється програмно.

Як було зазначено, отримані статистичні оцінки повинні задовольняти умовам Крамера-Рао і бути незміщеними, ефективними та оптимальними, тобто їх математичне сподівання $\mathrm{E}\left(\beta^{*}\right)$ та дисперсія $\mathrm{D}\left(\beta^{*}\right)$ матимуть мінімальні значення [3].Проведемо аналіз результатів оцінювання параметрів відносного пеленгу для вузькосмугових сигналів, отриманих за виразами (1) i (2) з визначенням математичного сподівання с та дисперсії $\mathrm{D}\left(\beta^{*}\right)$ оцінок відносного пеленгу. Враховуючи те, що щільність імовірності оцінки $\beta^{*}$, отриманої в результаті складної апаратурної обробки, у загальному випадку невідома, доцільно використати метод лінеаризації функцій кількох випадкових аргументів [3, 9]. Припустимо, що функція $\beta^{*}=\mathrm{f}\left(\mathrm{x}_{\mathrm{iC}}, \mathrm{x}_{\mathrm{iS}}\right), \mathrm{i}=1,2 \epsilon$ достатньо гладкою в області точки математичного сподівання $\mathrm{E}_{\mathrm{i}}\left(\mathrm{x}_{\mathrm{iC}}\right), \mathrm{E}_{\mathrm{i}}\left(\mathrm{x}_{\mathrm{iS}}\right)$ реалізації сигналу $x_{i}$. Це надає можливість 3 достатнім ступенем точності апроксимувати iї рядом Тейлора. Обмежуючись тільки лінійними членами розкладу функції $\mathrm{f}\left(\mathrm{x}_{\mathrm{iC}}, \mathrm{x}_{\mathrm{iS}}\right)$ та вважаючи квадратурні величини $\mathrm{x}_{1 \mathrm{C}}, \mathrm{x}_{1 \mathrm{~S}}, \mathrm{x}_{2 \mathrm{C}}, \mathrm{x}_{2 \mathrm{~S}}$ некорельованими, отримаємо таке значення математичного очікування оцінки пеленгу: 
$\mathrm{E}\left(\beta^{*}\right)=$
$=\arcsin \left(\frac{\lambda_{\mathrm{S}}^{*}}{2 \pi \mathrm{d}} \operatorname{arctg}\left[\frac{\mathrm{E}\left(\mathrm{x}_{1 \mathrm{C}}\right) \mathrm{E}\left(\mathrm{x}_{2 \mathrm{~S}}\right)-\mathrm{E}\left(\mathrm{x}_{1 \mathrm{~S}}\right) \mathrm{E}\left(\mathrm{x}_{2 \mathrm{C}}\right)}{\mathrm{E}\left(\mathrm{x}_{1 \mathrm{C}}\right) \mathrm{E}\left(\mathrm{x}_{2 \mathrm{C}}\right)+\mathrm{E}\left(\mathrm{x}_{1 \mathrm{~S}}\right) \mathrm{E}\left(\mathrm{x}_{2 \mathrm{~S}}\right)}\right]\right)$,

де $\mathrm{E}\left(\mathrm{x}_{1 \mathrm{C}}\right)=\mathrm{S} / 2 \cdot \cos (\psi+\phi) ; \mathrm{E}\left(\mathrm{x}_{1 \mathrm{~S}}\right)=-\mathrm{S} / 2 \cdot \sin (\psi+\phi)$; $\mathrm{E}\left(\mathrm{x}_{2 \mathrm{C}}\right)=\mathrm{S} / 2 \cdot \cos (\psi-\phi) ; \mathrm{E}\left(\mathrm{x}_{2 \mathrm{~S}}\right)=-\mathrm{S} / 2 \cdot \sin (\psi-\phi)-$ математичні сподівання квадратурних складових.

Отже, математичне сподівання оцінки $\beta^{*}$ пеленгу (3), знайдене тільки за лінійними членами ряду Тейлора функції $\mathrm{f}\left(\mathrm{x}_{\mathrm{iC}}, \mathrm{x}_{\mathrm{iS}}\right)$ можна вважати iї грубим значенням, яке дорівнює дійсному значенню відносного пеленгу $\beta_{\Gamma}^{*}$, що свідчить про незміщеність, достовірність та ефективність саме грубої оцінки параметрів. Дисперсія грубої оцінки $\mathrm{D}\left(\beta_{\Gamma}^{*}\right)$ у цьому випадку визначається за виразом:

$$
\mathrm{D}\left(\beta_{\Gamma}^{*}\right)=\sum_{\mathrm{i}=1}^{3}\left(\frac{\partial \beta^{*}}{\partial \mathrm{x}_{\mathrm{i}}}\right)_{\mathrm{E}}^{2} \sigma_{\mathrm{KB}}^{2},
$$

де $\mathrm{x}_{1}=\mathrm{x}_{1 \mathrm{C}} ; \mathrm{x}_{2}=\mathrm{x}_{1 \mathrm{~S}}, \mathrm{x}_{3}=\mathrm{x}_{2 \mathrm{C}}, \mathrm{x}_{4}=\mathrm{x}_{2 \mathrm{~S}}$ - квадратурні складові $\mathrm{x}_{\mathrm{i}} ; \sigma_{\mathrm{KB}}$ - дисперсія шуму у квадратурних каналах пеленгатора; Е - символ математичного сподівання величини $\mathrm{x}_{\mathrm{i}}$.

Вирішуючи $(2,3)$, як функцію (4), отримаємо:

$$
\mathrm{D}\left(\beta_{\Gamma}^{*}\right)=\frac{\lambda_{\mathrm{S}}^{2}}{2 \pi^{2} \mathrm{~d}^{2} \mathrm{q}^{2} \cos ^{2} \beta} .
$$

Характер зміни дисперсії оцінки пеленгу $\mathrm{D}\left(\beta_{\Gamma}^{*}\right)$ можна проаналізувати, задаючись фіксованими значеннями параметрів, від яких вона залежить, згідно з виразом (5). Хоча слід відмітити, що вираз (5) коректний лише для невеликої і достатньо лінійної ділянки функції (1), що знаходиться навколо нормалі до бази пеленгатора. Збільшити розміри цієї ділянки та уточнити результати, отримані за їх допомогою, можна використавши розклад функції $\beta=\mathrm{f}\left(\mathrm{x}_{\mathrm{i}}\right), \mathrm{i}=3$ в ряд Тейлора, де необхідно врахувати і третій квадратичний член [5]. У цьому випадку можна стверджувати, що отримані оцінки будуть мати більш точні значення $\beta_{\mathrm{t}}$, а математичне сподівання $\mathrm{E}\left(\beta_{\mathrm{T}}^{*}\right)$ та дисперсія $\mathrm{D}\left(\beta_{\mathrm{T}}^{*}\right)$ точної оцінки визначатиметься за такими виразами:

$$
\begin{gathered}
\mathrm{E}\left(\beta_{\mathrm{T}}^{*}\right)=\left[\mathrm{f}\left(\mathrm{x}_{\mathrm{i}}\right)\right]_{\mathrm{E}}+\frac{1}{2} \sum_{\mathrm{i}=1}^{4}\left(\frac{\partial^{2} \beta}{\partial \mathrm{x}_{\mathrm{i}}^{2}}\right)_{\mathrm{E}} \sigma_{\mathrm{KB}} \\
\mathrm{D}\left(\beta_{\mathrm{T}}^{*}\right)=\sigma_{\mathrm{KB}}^{2} \times \\
\times \sum_{\mathrm{i}=1}^{4}\left(\frac{\partial \beta^{*}}{\partial \mathrm{x}_{\mathrm{i}}}\right)_{\mathrm{E}}^{2}+\frac{1}{2} \sum_{\mathrm{i}=1}^{4}\left(\frac{\partial^{2} \beta}{\partial \mathrm{x}_{\mathrm{i}}^{2}}\right)_{\mathrm{E}}^{2} \sigma_{\mathrm{KB}}^{4}+\sum_{\mathrm{i}<\mathrm{j}}\left(\frac{\partial^{2} \beta}{\partial \mathrm{x}_{\mathrm{i}} \partial \mathrm{x}_{\mathrm{j}}}\right)_{\mathrm{E}}^{2} \sigma_{\mathrm{KB}}^{4} .
\end{gathered}
$$

Використовуючи похідні $\left(\frac{\partial^{2} \beta^{*}}{\partial x_{i}^{2}}\right)_{E}$, запишемо другий доданок правої частини виразу (7):

$$
\begin{aligned}
& \frac{1}{2} \sum_{\mathrm{i}=1}^{4}\left(\frac{\partial^{2} \beta^{*}}{\partial \mathrm{x}_{\mathrm{i}}^{2}}\right)_{\mathrm{E}} \sigma_{\mathrm{KB}}^{4}=\frac{2 \lambda_{\mathrm{S}}}{\pi \mathrm{d} \cos \beta} \frac{\sigma_{\mathrm{KB}}^{4}}{\mathrm{~S}^{2}} \times \\
& \times\left[2 \operatorname{tg} 2 \phi\left(1-\frac{1}{\cos ^{3} 2 \phi}\right)-\frac{\lambda_{\mathrm{S}}}{2 \pi \mathrm{d}} \frac{\operatorname{tg} \beta}{\cos \beta}\right] .
\end{aligned}
$$

3 урахуванням наведених вище виразів та нелінійного члена розкладу функції $\mathrm{f}\left(\mathrm{x}_{\mathrm{i}}\right)$ у ряд Тейлора (8), математичне сподівання точної оцінки відносного пеленгу можна записати у вигляді:

$$
+\frac{\lambda_{\mathrm{S}}^{2}}{2 \pi \mathrm{dq}^{2} \cos \beta}\left[2 \operatorname{tg} 2 \phi\left(1-\frac{1}{\cos ^{3} 2 \phi}\right)-\frac{\lambda_{\mathrm{S}}}{2 \pi \mathrm{d}} \frac{\operatorname{tg} \beta}{\cos \beta}\right],
$$

3 якого видно, що математичне сподівання збільшується на величину другого доданку виразу (9).

За виразом (9) в середовищі MathCAD проведені розрахунки і побудовані графічні залежності математичного сподівання $\mathrm{E}\left(\beta^{*}\right)$ від кута надходження радіосигналу відносно рівносигнального напрямку при лінійної та нелінійної апроксимації (рис. 1) за умови, що $\mathrm{q}^{2}=10 ; \mathrm{d}-0,5 \lambda$. На рисунку суцільною лінією показане математичне сподівання $\mathrm{E}\left(\beta^{*}\right)$ у лінійному наближенні, а пунктирною - 3 урахуванням нелінійного члена ряду Тейлора.

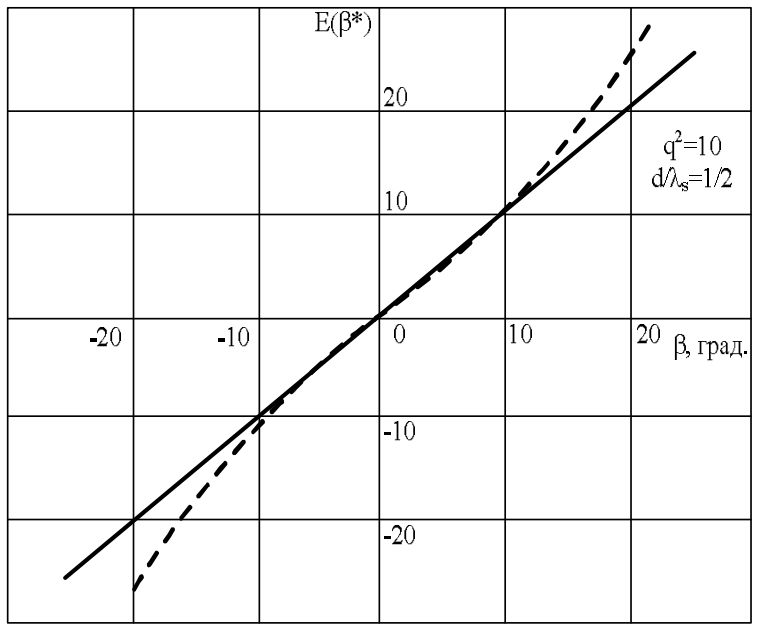

Рис. 1. Залежність математичного сподівання оцінки $\mathrm{E}\left(\beta^{*}\right)$ відносного пеленгу від кута надходження радіосигналу

3 наведеного графіку видно - уточнена зазначеним способом залежність $\mathrm{E}\left(\beta_{\mathrm{T}}^{*}\right)$ від величини відносного кута надходження радіосигналу має нелінійний характер, що свідчить про наявність нестабільної систематичної похибки при оцінюванні відносного пеленгу за лінійною, грубою моделлю $\mathrm{E}\left(\beta_{\Gamma}^{*}\right)$, яка зростає по мірі відхилення від рівносигнального напрямку. Це у багатьох практичних випадках $€$ однією 3 причин застосування моноімпульсних пристроїв лише для індикації точного наведення антени пеленгатора на ДРВп в процесі послідовного пеленгування. 
Рішення (7) з урахуванням (9) дає вираз для знаходження величини дисперсії точної оцінки відносного пеленгу $\mathrm{D}\left(\beta_{\mathrm{T}}^{*}\right)$, яке з урахуванням нелінійного члена ряду Тейлора, матиме вигляд [5]:

$$
\begin{gathered}
\mathrm{D}\left(\beta_{\mathrm{T}}^{*}\right)=\frac{\lambda_{\mathrm{S}}^{2}}{2 \pi^{2} \mathrm{~d}^{2} \mathrm{q}^{2} \cos ^{2} \beta}\left(1+\frac{1}{\mathrm{q}^{2}}\left[\frac{\lambda_{\mathrm{S}}}{\pi \mathrm{d}} \frac{\operatorname{tg} \beta}{\cos \beta} \times\right.\right. \\
\times\left(\frac{\lambda_{\mathrm{S}}}{4 \pi \mathrm{d}} \frac{\operatorname{tg} \beta}{\cos \beta}+\frac{2 \operatorname{tg} 2 \phi}{\cos ^{3} 2 \phi}-\operatorname{tg} 2 \phi\right)-\frac{\operatorname{tg} \beta \operatorname{tg} 2 \phi}{\cos \beta}+ \\
\left.\left.\quad+\operatorname{tg}^{2} 2 \phi\left(\frac{2,25}{\cos ^{6} 2 \phi}-\frac{4}{\cos ^{3} 2 \phi}+2,25\right)\right]\right) .
\end{gathered}
$$

Графік залежності дисперсії $\mathrm{D}\left(\beta^{*}\right)$ від кута надходження радіосигналу $\beta$ відносно рівносигнального напрямку, побудований за виразами (5 і 10), наведено на рис. 2, де суцільною лінією показано залежність дисперсії грубої оцінки у лінійному наближенні $\mathrm{D}\left(\beta_{\Gamma}^{*}\right)$, а пунктирною - 3 урахуванням нелінійного члена ряду Тейлора - точної оцінки $\mathrm{D}\left(\beta_{\mathrm{T}}^{*}\right)$.

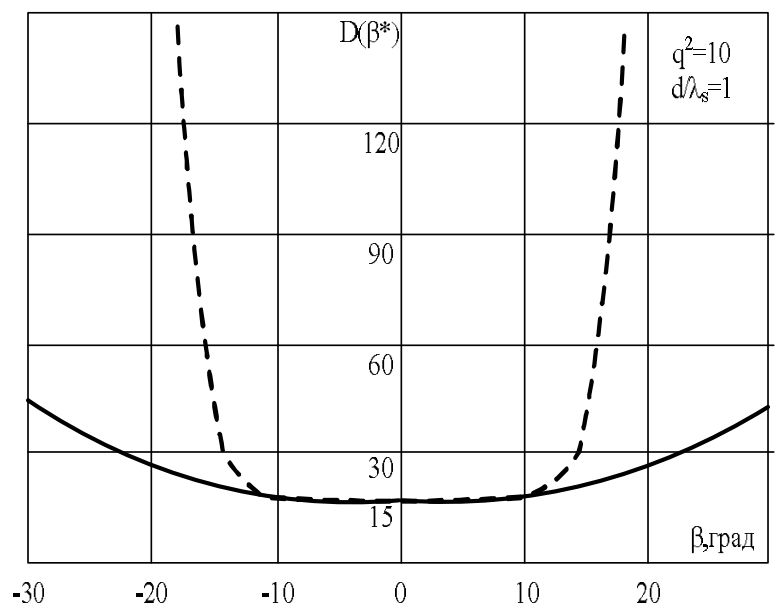

Рис. 2. Залежність дисперсії оцінки $\mathrm{D}\left(\beta^{*}\right)$ відносного пеленгу від кута надходження радіосигналу

Характер отриманих залежностей свідчить, що лінійна апроксимація визначення дисперсії оцінок відносного пеленгу дійсна лише у невеликому секторі навколо рівносигнального напрямку, як і було передбачено раніше. Уточнена за нелінійною складовою ряду Тейлора залежність дисперсії має більш виражені межі робочої ділянки сектору пеленгування, де похибки пеленгування мінімальні, що у свою чергу може бути індикатором лінійної ділянки дискримінаційної характеристики. 3 урахуванням наведеного, в подальшому можна казати про грубий і точний тракти пеленгування 3 відповідними дискримінаційними (пеленгаційними) характеристиками (ДХ), які реалізуються програмними засобами пристрою.

Аналіз залежності дисперсії оцінок пеленга $\mathrm{D}\left(\beta^{*}\right)$ у грубому $\left(\beta_{\Gamma}^{*}\right)$ та точному $\left(\beta_{\mathrm{T}}^{*}\right)$ трактах, розрахованих за виразом (9) для відношення сиг- нал/шум за потужністю $\mathrm{q}^{2}=10$ (рис. 2), показує, що на ДХ точного тракту існують кутові інтервали навколо точок розриву функцій $\operatorname{tg} 2 \phi$, де $\mathrm{D}\left(\beta_{\mathrm{T}}^{*}\right)$ швидко зростає до безкінечності. Це свідчить про суттєве погіршення точності пеленгування і втрату працездатності тракту точного пеленгування на цих ділянках через недостовірність отриманих оцінок точного пеленгу $\beta_{\mathrm{T}}^{*}$. В [5] показано, що для мінімізації похибок вимірювання відносного пеленгу доцільно використовувати додаткову зворотну, котангенціальну ДХ, яка формується програмно в спецобчислювачі. В цьому разі формується додатковий точний канал вимірювання $\beta_{\mathrm{T}}^{*}$ з уточненою дисперсією оцінок пеленгу:

$$
\begin{gathered}
\mathrm{D}^{\nabla}\left(\beta_{\mathrm{T}}^{*}\right)=\frac{\lambda_{\mathrm{S}}^{2}}{2 \pi^{2} \mathrm{~d}^{2} \mathrm{q}^{2} \cos ^{2} \beta}\left(1+\frac{1}{\mathrm{q}^{2}}\left[\frac { \lambda _ { \mathrm { S } } } { \pi \mathrm { d } } \frac { \operatorname { t g } \beta } { \operatorname { c o s } \beta } \left(\frac{\lambda_{\mathrm{S}}}{4 \pi \mathrm{d}} \frac{\operatorname{tg} \beta}{\cos \beta}+\right.\right.\right. \\
\left.+\frac{2 \operatorname{tg}(2 \phi+\pi / 2)}{\sin ^{3} 2 \phi}+\operatorname{tg}(2 \phi+\pi / 2)\right)+\frac{\operatorname{tg} \beta}{\cos \beta} \operatorname{tg}\left(2 \phi+\frac{\pi}{2}\right)+ \\
\left.\left.\operatorname{tg}^{2}(2 \phi+\pi / 2)\left(\frac{2,25}{\sin ^{6} 2 \phi}+\frac{4}{\sin ^{3} 2 \phi}+2,25\right)\right]\right) .
\end{gathered}
$$

Як приклад, за виразами $(5,10,11)$ в середовищі MathCAD проведені розрахунки величини дисперсії оцінок пеленгу у грубому і точному трактах пеленгатора за умови, що $\lambda_{\mathrm{H}}^{*}=3 \mathrm{~cm} ; \mathrm{d} / \lambda=3 ; \mathrm{q}^{2}=10$; $\phi=(\pi \mathrm{d} \cdot \sin \beta) / \lambda_{\mathrm{H}}$.

Результати розрахунків надані у вигляді графічних залежностей, наведених на рис. 3 , де залежність $\mathrm{D}^{\nabla}\left(\beta_{\mathrm{T}}^{*}\right)$ показана пунктиром.

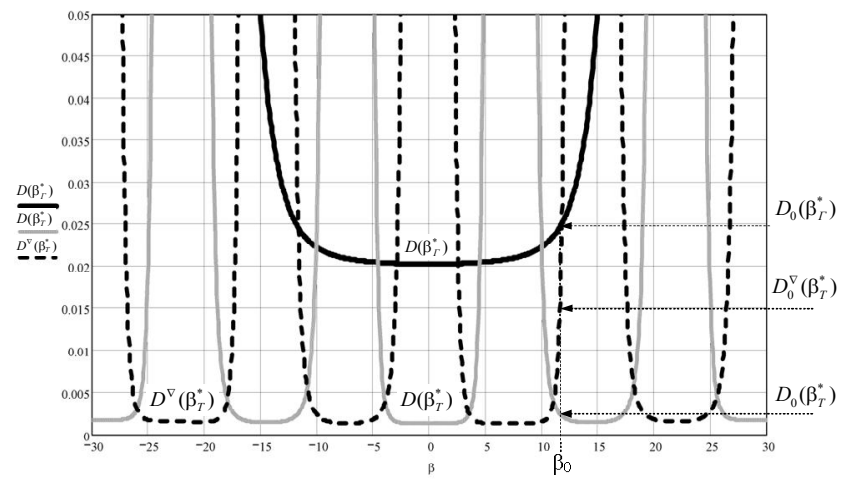

Рис. 3. Залежність дисперсії оцінок пеленгу у грубому і точному трактах пеленгатора

3 наведеного видно, що при програмному використанні додаткової ДХ дисперсія оцінки пеленгу набуває мінімальних значень саме на тих ділянках, де оцінка пеленгу за допомогою основної ДХ недостовірна або неможлива. Це у свою чергу свідчить про доцільність використання значень $\mathrm{U}_{\mathrm{T}}(\beta)$ i $\mathrm{U}^{\nabla}(\beta)$, як показників надійності відліків пеленгу, отриманих 
на певних ділянках ДХ точного тракту, з подальшим програмним вибором 3 них більш достовірного значення $\beta_{\mathrm{T}}^{*}$.

Крім того, необхідно відмітити, що завдяки програмному використанню додаткової оберненої ДХ та вибору точних оцінок пеленгу з мінімальною дисперсією, результуюча дисперсія у тракті точного пеленгування набуває більш гладкого характеру і величин, близьких до мінімальних значень.

\section{Висновки}

1. Завдання вимірювання параметрів джерел радіовипромінювань $є$ задачею оцінювання параметрів розподілу щільності імовірності за даними вибірки вхідної випадкової статистики.

2. При радіомоніторингу, що відбувається в умовах часткової або повної невизначеності, отримуються не значення параметрів вхідних сигналів, а їх оцінки, яки повинні задовольняти умовам Крамера-Рао і бути незміщеними, ефективними та оптимальними.

3. Незміщеність, ефективність та оптимальність оцінок повинна оцінюватися за величинами математичного сподівання і дисперсії параметрів джерел радіовипромінювань, яки матимуть мінімальні значення.

4. Мінімальні значення математичного сподівання і дисперсії параметрів джерел радіовипромінювань можна отримати тільки при коректному опису внутрішніх параметрів пристроїв радіомоніторингу. В багатьох випадках лінійна апроксимація внутрішніх параметрів призводить до великих похибок вимірювання і втрати незміщеності, ефективності та оптимальності статистичних оцінок сигналів.

5. Наведений підхід до аналізу статистичних оцінок параметрів, які підлягають апроксимації з використанням їх розкладу в ряд Тейлора, дає можливість підвищити точність визначення математичного сподівання і дисперсії оцінок. Його застосування, що розглянуто на прикладі пеленгування джерел радіовипромінювань моноімпульсними пеленгаторами, може забезпечити програмну мінімізацію математичного сподівання і дисперсії апаратно отриманих оцінок та бути поширено на визначення цілого ряду енергетичних, частотно-часових i просторових оцінок параметрів будь-якої радіотехнічної системи.

\section{Список літератури}

1. Радзиевский, В.Г. Теоретические основы радиоэлектронной разведки / В.Г. Радзиевский, А.А. Сирота. М.: Радиотехника, 2004. - 432 c.

2. Рембовский, А.М. Радиомониторинг: задачи, методы, средства / А.М. Рембовский, А.В. Аиимхин, В.А. Козьмин; Под ред. А.М. Рембовского. - М.: Горячая линия - Телеком, 2006. - 492 c.

3. Ільницький, A.I. Статистичні характеристики інформаційних ознак джерел випромінювання при радіомоніторингу телекомунікаційних мереж / A.I. Ільницький, О.І. Бурба, О.О. Пасічник // Управляющие системы и машины. - 2016. - № 6. - С. 48-58.

4. Галкин, В.А. Основы программируемого конфигурируемого радио / В.А. Галкин-М.: Горячая линия - Телеком, 2015. $-375 \mathrm{c}$.

5. Войтко, В.В. Спосіб двоканального фазового моноімпульсного пеленгування джерел радіовипромінювання станиіями радіомоніторингу / В.В. Войтко, А.І. Ільницький, А.А. Казаров // Декларачійний патент № 107503 на корисну модель U 201512210 - Бюл.№11, 10.06.2016.

6. Войтко, В.В. Пристрій двоканального однобазового моноімпульсного вимірювання пеленгу на джерело радіовипромінювання станціями радіомоніторингу на несучій частоті вхідних сигналів / В.В. Войтко, А.І. Ільницъький, А.А. Казаров // Деклараційний патент № 122275 на корисну модель U 201708068 - Бюл.№24, 26.12.2017.

7. Родс, Д.Р. Введение в моноимпульсную радиолокаиию / Пер. с англ. Б.М.Герасимова, Под ред. Л.Д. Бахраха. - М.: Сов.радио, $1960-160$ c.

8. Леонов, А.И. Моноимпульсная радиолокаџия / А.И.Леонов, К.И.Фомичев - М.: Сов. радио, 1970.-392 с.

9. Денисов, В.П. Фазовые радиопеленгаторы: Монография / В.П. Денисов - Томск: Томский гос. ун-т систем управления и радиоэлектроники, 2002. - 251 c.

Надійшла до редколегї 26.02.2018

Рецензент: д-р техн. наук, проф. К.С. Козелкова, Державний університет телекомунікацій, Київ.

\title{
СТАТИСТИЧЕСКИЕ ОЦЕНКИ НЕСМЕЩЕННОСТИ И ЭФФЕКТИВНОСТИ ПАРАМЕТРОВ ИСТОЧНИКОВ ИЗЛУЧЕНИЯ ПРИ РАДИОМОНИТОРИНГЕ ТЕЛЕКОММУНИКАЦИОННЫХ СЕТЕЙ И СИСТЕМ
}

\author{
А.И. Ильницкий, О.И. Бурба
}

Статья посвящена рассмотрению особенностей получения статистических оценок параметров источников радиоизлучения и характеристик их несмещенности, эффективности и оптимальности в процессе ведения радиомониторинга с моноимпульсным определением относительного пеленга радиотехнических элементов телекоммуникационных систем.

Ключевые слова: статистические оченки, точность пеленгования, источник радиоизлучений, радиомониторинг, моноимпульсное пеленгование, телекоммуникационные системы, несмещенность, эффективность, оптимальность.

\section{STATISTICAL ESTIMATIONS OF THE NON-DISPLACEMENT AND EFFICIENCY OF EMISSIONS SOURCE PARAMETERS AT RADIOMONITORING OF TELECOMMUNICATION NETWORKS AND SYSTEMS}

\section{A.I. Ilnitskiy, O.I. Burba}

The article is devoted to the consideration of the features of obtaining statistical estimates of the parameters of radio emission sources and the characteristics of their non-displacement, efficiency and optimality in the process of radiomonitoring with a monopulse determination of the relative bearing of radio engineering elements of telecommunication systems.

Keywords: statistical estimation, accuracy of direction finding, source of radio emissions, radio monitoring, monopulse direction finding, telecommunication systems, non-displacement, efficiency, optimality. 